\title{
MEASURING REVISIT INTENTIONS OF GREEN RESORTS IN MALAYSIA: THE ROLE OF PERCEIVED VALUE AND ENVIRONMENTAL CONCERN
}

\author{
Nor Rabiatul Adawiyah NOR AZAM* \\ Universiti Utara Malaysia, School of Tourism, Hospitality and Event Management, Sintok, Malaysia, e-mail: rabiatulnorazam@gmail.com
}

Ataul Karim PATWARY

Universiti Malaysia Kelantan, Faculty of Hospitality, Tourism and Wellness, Pengkalan Chepa, Malaysia, e-mail: ataul.kp@umk.edu.my

\author{
Basri RASHID
}

School of Tourism, Hospitality and Event Management, Universiti Utara Malaysia, Sintok, Malaysia, e-mail: basri@uum.edu.my

\begin{abstract}
Citation: Nor Azam, R.A.N., Patwary, A.K., \& Rashid, B. (2022). MEASURING REVISIT INTENTIONS OF GREEN RESORTS IN MALAYSIA: THE ROLE OF PERCEIVED VALUE AND ENVIRONMENTAL CONCERN. GeoJournal of Tourism and Geosites, 40(1), 157-166. https://doi.org/10.30892/gtg.40119-815
\end{abstract}

\begin{abstract}
The tourism industry in Malaysia serves an important role in providing high-quality tourism products and services and incorporating green practices to achieve environmental sustainability. Studies on the factors that influence revisit intention among green resort guests are limited. Thus, this study approached quantitative method and aimed to assess the influence of perceived value and environmental concern in measuring tourists revisit intentions of green resorts in Malaysia. The analysis unit is the resort's guests in the selected green resorts who have stayed in one of the selected green resorts for at least two days. A total of 450 sample data were analysed using the statistical software IBM SPSS version 22. This study fills the knowledge gap by proposing that environmental awareness and environmental knowledge influence guests' intention to revisit green resorts.
\end{abstract}

Key words: environmental concern, perceived value, revisit intention, green resorts

$* * * * * * *$

\section{INTRODUCTION}

The purpose of a green resort is to suit the demands and wants of its visitors. The term "green" refers to actions that reduce the environmental effect, alike eco-purchasing, or recycling (Han et al., 2011). According to Park and Kim (2017), green hotels follow ecologically friendly rules, practise environmental management, adopt a variety of ecofriendly practices, execute sound green programs, and pledge to enhance the environment by green globe emblem or ecolabel. Meeting client demands and desires must become the organisation's primary value driver. It is imperative that each worker grasps this notion and grows into a knowledgeable professional driven by a desire to provide excellent customer service and make customers happy. In today's competitive world, organisations need to do market research to explore new markets, analyze customer profiles according to their needs, and gather the information needed to create new products in response to evolving customer demand and desire trends (Hodgson, 1990; Kozak and Baloglu, 2011).

A better question may be, "What do people genuinely care about?" Companies must address these concerns concerning the perceived worth of products to consumers. To put it another way, a company's ability to add value to its goods and services, especially its service offerings or the service components of its business, is known as customer value (Salunke et al., 2019). Therefore, a person's willingness to engage in certain behaviours is shown by their Intention. Value and performance, promotional efforts and the spread of information about new attractions at the destination, may all influence the likelihood that customers will return to the same location again after a time. Customers are more likely to return to a resort if they previously visited one and found it efficient and affordable. According to Yang and Youngtae (2015), customers would undoubtedly reevaluate the value of a green resort after being inspired by an authentic experience. According to Grewal and Roggeveen (2020), several values dimensions might require differing based on the intensity of decision and what type of products or services being analysed. Revisit intention was examined through environmental concern and its indirect relationship via an individual's perception about environment.

\section{LITERATURE REVIEW AND CONCEPTUAL FRAMEWORK}

\section{Green Resort}

Any activity with less impact on the environment, such as eco-purchasing or recycling, is described as "green" (Han et al., 2011). Green resorts are environmentally friendly accommodations that use environmentally friendly techniques to protect the environment, such as water and energy conservation, trash reduction, and recycling and reusing durable service goods (Ashraf et al., 2020). Hospitality marketers are becoming more conscious of the possible competitive benefit of turning green. They have been more aggressive in seizing this potential by adopting proper tactics to be recognised as an

\footnotetext{
* Corresponding author
} 
ecologically friendly company (Shams et al., 2021). Green practises in Malaysia's hotel, and tourist business is still relatively new from a practical standpoint. Only ten hotels have met the ASEAN Green Hotel Standards 2016, according to the statistics data. The 9th Malaysian plan strengthened under the National Green Technology Policy (NGTP) in 2009 aimed to increase tourists' arrival by 2020 (Borhan et al., 2012). The hotel sector has already incorporated green and sustainability principles following these rules. This acceptance was evident in the tourist industry, which saw an increase of green hotels built in the following years (Huh and Chang, 2017). Aside from that, several hotels have begun to employ a variety of creative approaches to increase the "greenness" of their operations (Azam et al., 2017).

Environmental concerns in Malaysia become more important and understanding how decisions are made on how to devote their time, money and effort to various products and services is the focus of customer behaviour research (Kim et al., 2020). Academics from a wide range of disciplines have been interested in green behaviour over the last three decades. Empirical studies on what factors impact Malaysian tourists' behaviour toward green resorts are sparse (Ahn and Kwon, 2020). Consequently, the study's primary purpose is to bridge the knowledge gap about Malaysian customers' motivations for choosing green resorts. So, in this research, the green resort will be promoted as a place that will leave guests with a lasting impression and a good experience, influencing their desire to return for their next vacation.

\section{Environmental concern}

Concern about the environment is a significant factor influencing consumer decision-making (Adnan et al., 2017). Environmental concern is the degree of emotion and dedication to environmental concerns. This is an essential characteristic that essential characteristic may express an individual's compassions and environmental concerns. The new environmental paradigm is used to quantify environmental concerns, which vary from extremely highly unconcerned to very worried (Cruz, 2017).

\section{Environmental Knowledge}

Environmental knowledge is described as an individual's level of understanding of a topic that substantially influences their decision-making process (Abubakar et al., 2019). Basically, environmental knowledge has two forms (Khan et al., 2020). Consumers must be taught to understand the influence of consumer knowledge about the product itself must be developed in an ecologically sustainable manner. If clients are aware of environmental concerns, their knowledge level will rise, perhaps influencing them to return to green resorts.

\section{Environmental Awareness}

Customers are well aware of the significant environmental effects of their purchases (Wahid et al., 2011). This is primarily due to individuals being more environmentally conscious as they become more aware about environmental aspects (Rasheed et al., 2019). Consumer sensitivity to the environment has risen dramatically in the last decade in reaction to the need to reduce, if not eliminate, the adverse effects of human conduct on the environment (Joshi and Rahman, 2019). Customers are now attempting to fix environmental issues via their habits, since environmental concerns have become more prevalent. Resorts are currently developing more environmentally friendly products and services. Customers with increasing environmental concerns are expected to return to green resorts shortly.

\section{Perceived value}

Perceived value refers to a user's opinion or mental appraisal of the worth of a service or product to them (Wang et al., 2019). It is characterised as a two-part construct: one of the benefits of the user and the other of the user's sacrifices (Samudro et al., 2018). Therefore, key to a successful resort was to inspire happy sensations in the customers (Saeed et al., 2020). According to this study, the customer examines their consuming experience and their real experience to decide what benefits or sacrifices they feel they would get during a stay at a green resort.

\section{Functional value}

Functional value is "the perceived usefulness derived from an alternative's potential for functional, utilitarian, or physical performance" (Sheth et al., 1991:160). The consuming decision-making process is dominated by functional qualities and logical ideas, particularly when acquiring utilitarian things, where prevalent self-oriented value (Fraccaro, et al., 2021). The perceived value of green resorts is predicted to be positively influenced by their quality because this type of resort provides customers with eco-friendly linens, improved air quality, and the use of non-toxic material conducive to customers' having a healthy experience.

\section{Social Value}

"The benefit obtained from the product's potential to boost social self-concept" is how social value is defined (Sweeney and Soutar, 2001:16). The social value of a product or service is determined by its affiliation with socioeconomic, demographic, and cultural-ethnic groups that are positively or negatively stereotyped. As a result, customers in this research saw society as a place where they may benefit from interacting with other individuals. When a customer feels linked to other individuals, they can receive value.

\section{Epistemic value}

The desire to experience something different or a whole new experience provides customers with epistemic value. Epistemic value is "the perceived utility acquired from an alternative's capacity to arouse curiosity, provide novelty, and satisfy a desire for knowledge" (Sheth et al., 1991; Suki et al., 2021). In this current study, the value will be generated when the customers' desire for knowledge and curiosity on any aspect of the green resort is fulfilled. 


\section{Emotional value}

The emotional value represents "the perceived benefit of an alternative emotion or an alternative ability to evoke an emotional state" (Sheth et al., 1991; Yrjölä et al., 2019). Different types of goods and services are associated with emotions. In this study, customers will develop positive and negative emotions related to the experience at the green resort, especially feelings of comfort and enjoyment, the ability to describe the overall experience and sometimes the feeling of surprise due to certain pleasant situations that they have never encountered before.

\section{Revisit Intention}

Customers who have had past encounters with hotels or resorts that they consider very useful in terms of efficiency and economic elements are more inclined to return; they are more likely to lead to a desire to return (An et al., 2019). Repeat visitors are tourists knowledgeable of their location and have high expectations based on prior experiences (Su and Swanson, 2017). Similarly, repeat visitors' intentions might also be influenced by the promotional efforts of tourist destinations that could assist them in recalling their positive memories with the products or services before performing their corresponding behaviours in the future. For example, disseminating information on the tourist attractions voluntarily and revisiting them (Lukuyu et al., 2012). Similarly, past tourism studies also found that post-visit evaluations would lead to higher levels of tourists' intentions to revisit a particular destination and recommend it to their families and friends (Azali et al., 2021). In this study, researchers explore the importance of influencing factors such as environmental issues and values in Ia customer's intention to return to a green resort.

\section{Proposed Conceptual Model}

Accordingly, this study adapted and modified a research framework proposed in a prior study by Yang and Youngtae (2015) on the influence of perceived green value on green hotel guests' propensity to revisit green hotels. The current study was expected to extend the prior study to grasp how the guests value their decision to stay in a green lodging through their personal experience. Potential trade-off in the relationship between green resorts and their guests, and how these guests would reflect these values on their revisit intention.

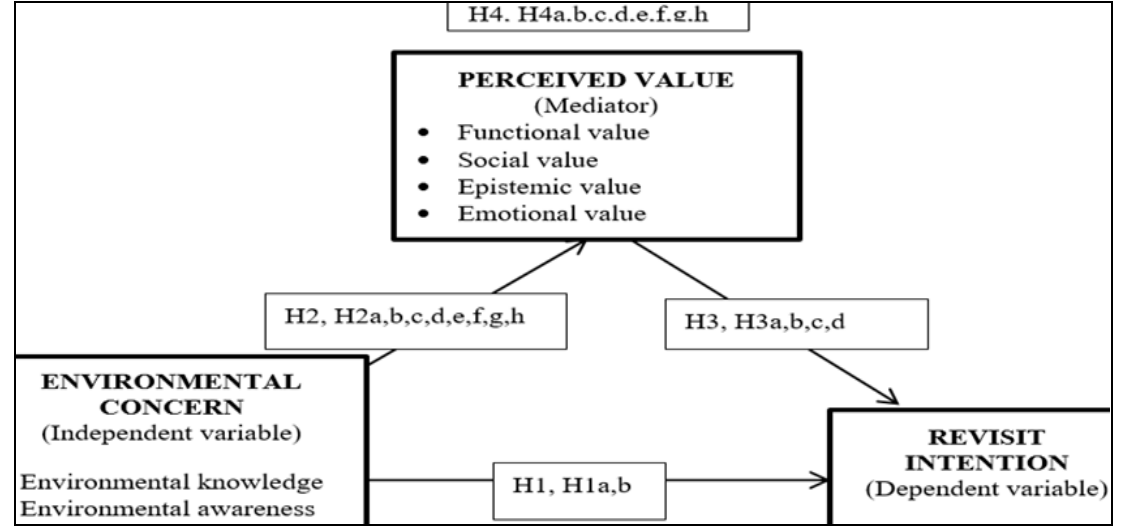

Figure 1. The influence of environmental concern dimensions and perceived value dimensions on customers' intention to revisit green resort

\section{RESEARCH METHODOLOGY}

To gather the information needed for this investigation, researchers used a questionnaire survey. The variables needed to answer the study question and test any relevant hypotheses are measured using a structured questionnaire. The survey's primary goal is to learn how respondents feel and think about the events and concerns (Collis and Hussey, 2009). As a result, a thorough review of the relevant literature was conducted before compiling the questions. The question scale design was adopted by the Likert scale (Churchill, 1999). In this survey, it was decided to carry out a seven-point scale measurement in the questionnaire. In this case, a multi-level 7-point scale is used: A score of " 1 " is depicted as strongly disagree up to "7" as strongly agree are used in measurement of environmental knowledge, environmental awareness, functional value, epistemic value. The social value determines whether the customers view society as where they can obtain some benefits through their interaction with other people. In terms of scale, the 7-point Likert scale measurement is used, from 1 = "Not at all important" to 7 = "Extremely important".

The emotional value determines whether the experience of the visit will lead to tourists' positive or negative emotions. The 12 items comprise six positive (joyful, happiness, excitement, calmness, surprise, relaxed) and six negative (annoyed, upset, frustrated, anger, sadness, and boredom). Specifically, the customers will be asked to what extent had they experienced these twelve emotions during their visit, ranging from 1 = "I have not experienced this emotion at all" to $7=$ "I have strongly experienced this emotion". Revisit 5 items explain intentions. The revisit intentions measure the customers' intention to revisit the destination and recommend others to visit the destination (Kozak and Baloglu, 2011; Rashid, 2013). In terms of scale, the 7-points Likert scale measurement is used ranging from $1=$ "Not likely at all" to 7 = "Definitely". The current study involved 450 green resort guests who stayed for two nights or more in these three selected green resorts. A total of 600 questionnaires were distributed at the beach of the green resorts. The data of this study were analysed with 450 data using the IBM SPSS version 22.

\section{RESULTS}

\section{Demographic Profile of Respondents}

Table 1 presents the demographic profile of 450 respondents from three selected green resorts in the northern region of Peninsular Malaysia who took part in the study's questionnaire survey. Most of the respondents were female (63.1\%). In addition to that, most of the respondents were between the age of 26 and 40 years $(48.1 \%)$, which was followed by of those who were below 25 years of age (28.7\%) and between 41 and 55 years of age (14.7\%). Only 8.2\% of the total respondents 
were above 55 years. In addition, some respondents were from other countries (69.3\%), such as Argentina, Britain, United Arab Emirates, Sweden, France, Germany, Iran, China, Australia, the United States of America, Holland, and Norway. The remaining 30.7\% were Malaysians. Meanwhile, a large proportion of these respondents were employed in the private sector $(60.0 \%)$. There were $27.8 \%$ who were self-employed and $12.2 \%$ who were employed in the government sector.

Table .1 Demographic Profile of Respondents

\begin{tabular}{|l|l|c|c|}
\hline $\begin{array}{c}\text { Demographic } \\
\text { information }\end{array}$ & \multicolumn{1}{|c|}{ Categories } & $\begin{array}{c}\text { Frequency } \\
\text { (n) }\end{array}$ & $\begin{array}{c}\text { Percentage } \\
(\%)\end{array}$ \\
\hline Gender & Male & 166 & 36.9 \\
& Female & 284 & 63.1 \\
\hline Age & Below 25 & 129 & 28.7 \\
& 26-40 & 218 & 48.4 \\
& $41-55$ & 66 & 14.7 \\
& 56 or over & 37 & 8.20 \\
\hline Nationality & Malaysian & 138 & 30.7 \\
& Non-Malaysian & 312 & 69.3 \\
\hline Employment & Government & 55 & 12.2 \\
sector & Private & 270 & 60.0 \\
& Self-employed & 125 & 27.8 \\
\hline Occupation & Executive & 49 & 11.0 \\
& Professional & 135 & 30.0 \\
& Business & 195 & 43.3 \\
& Others & 71 & 15.7 \\
\hline Salary scale & RM 1,000 and below & 34 & 7.6 \\
& RM 1,001-RM 2,000 & 16 & 3.6 \\
& RM 2,001-RM 3,000 & 111 & 24.7 \\
& RM 3,001-RM 4,000 & 59 & 13.1 \\
& RM4,001 and above & 230 & 51.0 \\
\hline Purpose of stay & Leisure & 309 & 68.7 \\
& Business & 20 & 4.4 \\
& Business and leisure & 32 & 7.1 \\
& Other & 89 & 19.8 \\
\hline Length of stay & 2 & 12 & 2.7 \\
(nights) & 3-4 & 277 & 61.6 \\
& 5-7 & 105 & 23.3 \\
& More than 7 & 56 & 12.4 \\
\hline Solo or group & Solo & 44 & 9.80 \\
travel & With partner or spouse & 138 & 30.7 \\
information on & Family with children & 131 & 29.1 \\
the green resort & With parents & 42 & 9.30 \\
& With friends & 95 & 21.1 \\
\cline { 2 - 5 } & Triends and relatives & 35 & 11.6 \\
& Travel or tour agency & 197 & 7.80 \\
& Tourism Malaysia & 28 & 12.0 \\
& Personal experience & 84 & 6.20 \\
& & & \\
& & 5.7 \\
\hline
\end{tabular}

Table 2. Results of Reliability Analysis

\begin{tabular}{|c|c|}
\hline Construct & Cronbach's alpha coefficient (a) \\
\hline Environmental concern & \\
\hline Environmental knowledge & 0.720 \\
\hline Environmental awareness & 0.787 \\
\hline Perceived value & \\
\hline Functional value & 0.879 \\
\hline Social value & 0.871 \\
\hline Epistemic value & 0.933 \\
\hline Emotional value & 0.710 \\
\hline Revisit Intention & 0.931 \\
\hline
\end{tabular}

Table 3. Results of Simple Regression Analysis for Environmental Concern and Revisit Intention to the Green Resorts in Malaysia

\begin{tabular}{|c|c|c|c|c|}
\hline Constructs & B & SE B & $\boldsymbol{\beta}$ & Sig. \\
\hline Environmental knowledge & 0.062 & 0.055 & 0.045 & 2.57 \\
\hline Environmental awareness & 0.673 & 0.46 & 0.590 & .000 \\
\hline $\mathrm{R}=0.608$ & & & & \\
\hline $\mathrm{R}^{2}=3.67$ & & & & \\
\hline $\mathrm{F}=130.929$ & & & & \\
\hline
\end{tabular}

Table 4. Results of Simple Regression Analysis for Environmental Concern and Perceived Functional Value

\begin{tabular}{|l|c|c|c|c|}
\hline \multicolumn{1}{|c|}{ Constructs } & B & SE B & $\boldsymbol{\beta}$ & Sig. \\
\hline Environmental knowledge & -0.083 & 0.050 & -0.063 & 1.01 \\
\hline Environmental awareness & 0.726 & 0.042 & 0.665 & .000 \\
\hline $\mathrm{R}=0.646$ & & & & \\
\hline $\mathrm{R}^{2}=0.414$ & & & & \\
\hline $\mathrm{F}=159.856$ & & & & \\
\hline
\end{tabular}

Table 5.Results of Simple Regression Analysis for Environmental Concern and Perceived Social Value

\begin{tabular}{|l|c|c|c|c|}
\hline \multicolumn{1}{|c|}{ Constructs } & B & SE B & $\boldsymbol{\beta}$ & Sig. \\
\hline Environmental knowledge & 0.170 & 0.077 & 0.093 & .029 \\
\hline Environmental awareness & 0.770 & 0.065 & 0.504 & .000 \\
\hline $\mathrm{R}=0.646$ & & & & \\
\hline $\mathrm{R}^{2}=0.414$ & & & & \\
\hline $\mathrm{F}=159.856$ & & & & \\
\hline
\end{tabular}

As for the occupation aspect, business (43.3\%), which was followed by those who were from the professional level $(30.0 \%)$ and executive-level $(11.0 \%)$. Regarding the salary scale, $51.0 \%$ of the total respondents earned more than RM 4,001 and 24.7\% earned between RM 2,001 and RM 3,000. Others earned between RM 3,001 and RM 4,000 (13.1\%). Adding to that, a vast majority of these respondents regarded leisure as the most important reason for their stay in the green resorts $(68.7 \%)$, followed by business and leisure $(7.1 \%)$, and lastly, business purpose (4.4\%). It is assumed that the green resort guests could consume the relevant products and services during their stay in the green resorts for at least two nights. Hence, the length of stay was categorised as follows: (1) 2 nights; (2) 3-4 nights; (3) 5-7 nights; (4) more than 7 nights. In terms of the length of stay, most of the respondents stayed for three to four nights $(61.6 \%)$, followed by those who stayed for five to seven nights (23.3\%). The remaining stayed for more than seven nights (12.4\%), and only $2.7 \%$ stayed for two nights. These respondents mostly travelled with their partner or spouse $(30.7 \%)$ or as a family with children (29.1\%). This study also acquired information on how the respondents were aware of the green resorts. The obtained data revealed that $44.0 \%$ of the respondents obtained information from the Internet, whereas $18.7 \%$ gained information on the green resorts from their personal experience. Others were introduced to the green resorts through the television or newspaper (11.6\%), friends and relatives (7.8\%), and Tourism Malaysia (6.2\%).

\section{Reliability Test}

Table 2 shows that the Cronbach's alpha values were above the minimum acceptable value given by Hair et al. (2010), which was 0.6 for social science research, based on the data obtained from the study. According to the findings, the constructs had an adequate internal consistency, with values ranging from 0.707 to 0.943 . In other words, the assessed components, particularly the constructs of epistemic value, social value, and revisit intention, had strong internal consistency. In light of the literature on measuring scales, this investigation determined that the instrument was reliable in 
internal consistency (Hair et al., 2010). As a result, the questionnaire is considered official and may be utilised in future research. For clarity and to prevent misunderstanding, one item of emotional significance was removed from Table 2. Before the actual data collection, a pilot study was done to assess the validity and reliability of the survey instruments (Sekaran, 2000). The replies indicated that they were unsure about the definition of 'annoyance.' Cronbach's alpha for reliability test findings are as follows:

Referring to the proposed framework in Figure 1, all proposed hypotheses for testing are presented in the following:

H1 "Environmental concern influences the revisit intention to the green resorts".

$\mathrm{H}_{1}$ " "Environmental knowledge influences the revisit intention to the green resorts".

$\mathrm{H} 1_{\mathrm{b}}$ "Environmental awareness influences the revisit intention to the green resorts".

H2 "Environmental concern influences the dimensions of the perceived value of the green resort guests".

$\mathrm{H} 2_{\mathrm{a}}$ "Environmental knowledge influences the perceived functional value".

$\mathrm{H} 2_{\mathrm{b}}$ "Environmental awareness influences the perceived functional value".

$\mathrm{H} 2_{c}$ "Environmental knowledge influences the perceived social value".

$\mathrm{H} 2_{\mathrm{d}}$ "Environmental awareness influences the perceived social value".

$\mathrm{H} 2_{\mathrm{e}}$ "Environmental knowledge influences the perceived epistemic value".

$\mathrm{H} 2_{\mathrm{f}}$ "Environmental awareness influences the perceived epistemic value".

$\mathrm{H} 2_{\mathrm{g}}$ "Environmental knowledge influences the perceived emotional value".

$\mathrm{H} 2_{\mathrm{h}}$ "Environmental awareness influences the perceived emotional value".

H3 "Perceived value influences the revisit intention to the green resorts".

$\mathrm{H} 3_{\mathrm{a}}$ "Perceived functional value influences the revisit intention to the green resorts".

$\mathrm{H} 3{ }_{\mathrm{b}}$ "Perceived social value influences the revisit intention to the green resorts".

$\mathrm{H} 3_{\mathrm{c}}$ "Perceived epistemic value influences the revisit intention to the green resorts".

$\mathrm{H} 3_{\mathrm{d}}$ "Perceived emotional value would influence customers' intention to revisit green resorts".

H4 "Perceived value mediates the relationship between environmental concern and revisit intention to the green resorts".

$\mathrm{H} 4{ }_{\mathrm{a}}$ "Perceived functional value mediates the relationship between environmental knowledge and revisit intention to the green resorts".

$\mathrm{H} 4$ b "Perceived social value mediates the relationship between environmental knowledge and revisit intention to the green resorts".

$\mathrm{H} 4_{\mathrm{c}}$ "Perceived epistemic value mediates the relationship between environmental knowledge and revisit intention to the green resorts".

$\mathrm{H} 4_{\mathrm{d}}$ "Perceived emotional value mediates the relationship between environmental knowledge and revisit intention to the green resorts".

$\mathrm{H} 4$ e "Perceived functional value mediates the relationship between environmental awareness and revisit intention to the green resorts".

$\mathrm{H} 4_{\mathrm{f}}$ "Perceived social value mediates the relationship between environmental awareness and revisit intention to the green resorts".

$\mathrm{H} 4_{\mathrm{g}}$ "Perceived epistemic value mediates the relationship between environmental awareness and revisit intention to the green resorts".

$\mathrm{H} 4$ h "Perceived emotional value mediates the relationship between environmental awareness and revisit intention to the green resorts".

\section{Hypothesis Testing}

This study conducted a simple regression analysis to test the hypotheses. The obtained results in Table 3 revealed that environmental concern explained $36.7 \%\left(\mathrm{R}^{2}=0.367\right)$ of the total variance in the revisit intention to the green resorts $(\mathrm{F}=$ $130.929, \mathrm{p}=.000)$. In this case, the positive relationship between environmental awareness and revisit intention was statistically significant $(\beta=0.590, \mathrm{t}=14.724, \mathrm{p}=.000)$. However, the relationship between environmental knowledge and revisit intention was not significant $(\beta=0.045, \mathrm{t}=1.134, \mathrm{p}>.05)$; thus, rejecting $\mathrm{H} 1_{\mathrm{a}}$. In addition, the obtained beta values revealed that environmental awareness, compared to environmental knowledge, contributed a higher influence in predicting the revisit intention to the green resorts; therefore, $\mathrm{H}_{\mathrm{b}}$ was supported.

The obtained results in Table 4 revealed that environmental concern explained $41.4 \%\left(\mathrm{R}^{2}=0.414\right)$ of the total variance in the perceived functional value $(\mathrm{F}=159.86, \mathrm{p}=.000)$. In this case, the relationship between environmental awareness and perceived functional value was statistically significant $(\beta=0.665, \mathrm{t}=17.254, \mathrm{p}=.000)$. Nevertheless, the relationship between environmental knowledge and perceived functional value was not significant $(\beta=-0.063, \mathrm{t}=-1.645, \mathrm{p}>.05)$; thus, rejecting $\mathrm{H} 2$ a. In addition, the obtained beta values indicated that environmental awareness, compared to environmental knowledge, contributed a higher influence in predicting the perceived functional value; thus, $\mathrm{H} 2_{\mathrm{b}}$ was supported.

Referring to Table 5, this study found that the environmental concern explained $29.2 \%\left(R^{2}=0.292\right)$ of the total variance in the perceived social value $(\mathrm{F}=93.62, \mathrm{p}=.00)$. The relationship between environmental knowledge and perceived social value was statistically significant $(\beta=0.077, \mathrm{t}=2.195, \mathrm{p}=.0029)$. Likewise, the relationship between environmental awareness and perceived social value was significant $(\beta=0.504, \mathrm{t}=-11.883, \mathrm{p}=.000)$.

In other words, both $\mathrm{H} 2_{c}$ and $\mathrm{H} 2_{\mathrm{d}}$ were supported in this study. Despite that, the obtained beta values indicated that environmental awareness contributed to higher influence in predicting perceived social value than environmental knowledge. Referring to Table 6, the obtained results revealed that environmental concern explained $43.3 \%$ of the total 
variance in the perceived epistemic value $\left(\mathrm{R}^{2}=0.433, \mathrm{~F}=172.341, \mathrm{p}<.01\right)$. This study also found that the relationship between environmental awareness and the perceived epistemic value was statistically significant and positive $(\beta=0.697, \mathrm{t}$ $=18.358, \mathrm{p}<.01)$. On the other hand, environmental knowledge had a significant and negative relationship with the perceived epistemic value $(\beta=-0.146, \mathrm{t}=-3.836, \mathrm{p}<.01)$. In addition, the obtained beta values indicated that environmental awareness, compared to environmental knowledge, contributed a higher influence in predicting the perceived epistemic value. In this case, both $\mathrm{H} 2_{\mathrm{e}}$ and $\mathrm{H} 2_{\mathrm{f}}$ were supported in this study.

Table 6. Results of Simple Regression Analysis for Environmental Concern and Perceived Epistemic Value

\begin{tabular}{|l|c|c|c|c|}
\hline \multicolumn{1}{|c|}{ Constructs } & B & SE B & $\boldsymbol{\beta}$ & Sig. \\
\hline Environmental knowledge & -0.235 & 0.061 & -0.146 & .000 \\
\hline Environmental awareness & 0.943 & 0.051 & 0.697 & .000 \\
\hline $\mathrm{R}=0.660$ & & & & \\
\hline $\mathrm{R}^{2}=0.433$ & & & & \\
\hline $\mathrm{F}=172.341$ & & & & \\
\hline
\end{tabular}

Referring to Table 7 , environmental concern was found to explain $9.9 \%\left(\mathrm{R}^{2}=.099\right)$ of the total variance in the perceived emotional value $(\mathrm{F}=25.766, \mathrm{p}=.000)$. Both relationships that involved environmental knowledge $(\beta=0.139, \mathrm{t}=$ $2.903, \mathrm{p}=.004)$ and environmental awareness $(\beta=0.245, \mathrm{t}=5.134 \mathrm{p}<.01)$ significantly contributed to the prediction of perceived emotional value. The obtained beta values also indicated that environmental awareness contributed a higher influence in predicting the perceived emotional value. Based on the obtained results, both $\mathrm{H} 2_{\mathrm{g}}$ and $\mathrm{H} 2_{\mathrm{h}}$ were supported in this study. Using basic regression methodology, this research examined Hypothesis 3 on the link between revisit intention, and perceived value to green resorts. The findings demonstrated that functional value $(=0.0456, \mathrm{t}=10.706, \mathrm{p}=.000)$ and epistemic value $(=0.0285, \mathrm{t}=5.781, \mathrm{p}=.000)$ explained $55.7 \%$ variance in revisit intention. Out of all the components examined in this research, the functional value had the greatest impact in predicting revisit intention, with a standardized beta of 0.456 . As a result, the functional value was the most significant predictor of revisit intention, followed by the epistemic value (standardized beta of 0.285$)$. Social value $(=0.080, \mathrm{t}=1.689, \mathrm{p}=.092)$ and emotional value $(=0.037, \mathrm{t}=$ $1.058, \mathrm{p}=.291$ ) were also found. Only $\mathrm{H} 3 \mathrm{a}$ and $\mathrm{H} 3 \mathrm{c}$ (functional and epistemic value) were supported in this research. In contrast, the other two hypotheses (H3b and H3d) (social and emotional worth) were rejected due to a p-value larger than 0.05 .

\section{Perceived Value as the Mediator}

This study assessed the mediating role of perceived value in the relationship between environmental concern and revisit intention through four hypothesised paths according to the proposed method by Barron and Kenny (1986). This study found that the relationship between environmental knowledge and revisit intention was not statistically significant $(\beta=0.045, \mathrm{t}=1.134, \mathrm{p}>.05)$. Thus, the initial requirement of this mediating test was not met. As patch $c$ was not established, there was no need for this study to proceed with the ensuing analysis to assess the mediation effect of perceived value (functional value, social value, epistemic value, and emotional value). In other words, the study could not confirm the mediation effect of perceived value in the relationship between environmental knowledge and revisit intention to the green resorts. This study initially assessed the relationship between environmental awareness and revisit intention $(c)$, which revealed that the relationship was statistically significant $(\beta=0.590, \mathrm{t}=14.724, \mathrm{p}=.000)$.

The study first assessed the relationship between environmental awareness and perceived functional value $(a)$, which indicated that the relationship was also significant $(\beta=0.665, \mathrm{t}=17.254, \mathrm{p}=.000)$. Following that, this study assessed the effect of the relationship between environmental awareness and perceived functional value on revisit intention $(b)$. The results revealed that this path was also significant $(\beta=.0456, \mathrm{t}=10.706, \mathrm{p}=.000)$. The obtained results demonstrated the significance of the relationship between environmental awareness and revisit Intention $(\beta=0.272, \mathrm{p}<$ .01 ), but with a slight reduction of unstandardised coefficient $(\beta)$. Perceived functional value was found to mediate thIis study's relationship between environmental awareness and revisit Intention to the green resorts.

To reaffirm this partial mediation, this study conducted the Sobel test, which revealed statistical significance $(\mathrm{t}=$ $8.772, \mathrm{p}<.01)$. In other words, a partial mediation occurred; thus, supporting H4e. Concerning $\mathrm{H} 4_{\mathrm{f}}$, this study assessed the effect of the relationship between environmental awareness and perceived social value $(a)$, which revealed that the relationship was significant $(\beta=0.504, \mathrm{t}=-11.883, \mathrm{p}=.000)$. However, the effect of the relationship between environmental awareness and perceived social value on revisit intention $(b)$ was not significant $(\beta=0.080, \mathrm{t}=1.689, \mathrm{p}=$ .092). With that, the study was not able to proceed with the subsequent analysis.

As a result, this study could not confirm the mediation effect of perceived social value on the relationship between environmental awareness and revisit Intention (H4f). Apart from that, this study found that the relationship between environmental awareness and perceived epistemic value $(a)$ was significant $(\beta=0.697, \mathrm{t}=18.358, \mathrm{p}<.01)$. Similarly, the effect of the relationship between environmental awareness and perceived epistemic value on revisit intention $(b)$ was also significant $(\beta=0.0285, \mathrm{t}=5.781, \mathrm{p}=.000)$. This led to the analysis of the effect of environmental awareness on revisit intention, controlling the effect of perceived epistemic value $\left(c^{\prime}\right)$. It was revealed that the relationship between environmental awareness and revisit Intention was significant $(\beta=0.330, \mathrm{p}<.01)$, but with a reduction in unstandardised coefficient $(\beta)$. Additionally, a partial mediation of perceived epistemic value on the relationship between environmental awareness and revisit intention to the green resorts occurred and was further reaffirmed using the Sobel test $(\mathrm{t}=7.827, \mathrm{p}<$ $.01)$. Thus, H4g was supported in this study. Finally, this study also assessed the relationship between environmental 
awareness and perceived emotional value $(a)$ concerning $\mathrm{H} 4 \mathrm{~h}$. In this case, path $a$ was found significant $(\beta=0.245, \mathrm{t}=$ $5.134 \mathrm{p}<.01)$. However, the effect of the relationship between environmental awareness and perceived emotional value on revisit intention $(b)$ was not significant $(\beta=0.037, \mathrm{t}=1.058, \mathrm{p}=.291)$. Therefore, the study could not proceed with the ensuing analysis on confirming the mediation effect of perceived emotional value in the relationship between environmental awareness and revisit intention. Accordingly, this study conducted a series of regression analyses. The obtained regression analysis results are summarised in Table 8 and Table 9, which demonstrates the mediating role of functional value and epistemic value in the significant relationship between environmental awareness and revisit intention to the green resorts. Meanwhile, the social value and emotional value were found to have no mediation effect on the relationship between environmental awareness and revisit intention to the green resorts.

Table 8. Results of simple regression analysis for perceived value and revisit intention

\begin{tabular}{|l|l|c|c|c|c|c|}
\hline & & \multicolumn{3}{|c|}{$\begin{array}{l}\text { Unstandardised } \\
\text { Coefficient }\end{array}$} & \multicolumn{3}{|c|}{$\begin{array}{c}\text { Standardised } \\
\text { coefficient }\end{array}$} \\
\hline Model & & B & Std. Error & B & t-value & Sig. \\
\hline & (Constant) & 1.420 & .220 & & 6.440 & .000 \\
\hline & $\begin{array}{l}\text { Functional } \\
\text { value }\end{array}$ & .476 & .044 & .456 & 10.706 & .000 \\
\hline & $\begin{array}{l}\text { Social } \\
\text { value }\end{array}$ & .060 & .035 & .080 & 1.689 & .092 \\
\hline & $\begin{array}{l}\text { Epistemic } \\
\text { value }\end{array}$ & .241 & .042 & .285 & 5.781 & .000 \\
\hline & $\begin{array}{l}\text { Emotional } \\
\text { value }\end{array}$ & .060 & .057 & .037 & 1.058 & 0291 \\
\hline $\mathrm{R}=0.747$ & \\
\hline $\mathrm{R}^{2}=0.557$ & $\mathrm{~F}=140.084$ \\
\hline $\mathrm{p}<.001$ &
\end{tabular}

Table 9. Results of regression analysis on the mediation effect of perceived value on the relationship between environmental awareness and revisit intention Note: $Y$ denotes the dependent variable, which is the revisit intention to the green resorts

\begin{tabular}{|c|c|c|c|c|c|}
\hline $\begin{array}{l}\text { Independent } \\
\text { variable (X) }\end{array}$ & $\begin{array}{l}\text { Mediator } \\
\text { (M) }\end{array}$ & Path & $\begin{array}{c}\text { Coefficients } \\
\text { (B) }\end{array}$ & Sig. & Results \\
\hline \multirow{16}{*}{$\begin{array}{l}\text { Environmental } \\
\text { awareness }\end{array}$} & \multirow{4}{*}{$\begin{array}{l}\text { Functional } \\
\text { value }\end{array}$} & $\mathrm{X} \rightarrow \mathrm{Y}(c)$ & 0.590 & .000 & \multirow{4}{*}{$\begin{array}{c}\text { Partial } \\
\text { mediation }\end{array}$} \\
\hline & & $\mathrm{X} \rightarrow \mathrm{M}(a)$ & 0.665 & .000 & \\
\hline & & $\mathrm{X} \rightarrow \mathrm{M} \rightarrow \mathrm{Y}(b)$ & 0.456 & .000 & \\
\hline & & $\mathrm{X} \rightarrow \mathrm{Y} \rightarrow \mathrm{M}\left(c^{\prime}\right)$ & 0.272 & .000 & \\
\hline & \multirow{4}{*}{$\begin{array}{l}\text { Social } \\
\text { value }\end{array}$} & $\mathrm{X} \rightarrow \mathrm{Y}(c)$ & 0.590 & .000 & \multirow{4}{*}{$\begin{array}{c}\text { No } \\
\text { mediation }\end{array}$} \\
\hline & & $\mathrm{X} \rightarrow \mathrm{M}(a)$ & 0.504 & .000 & \\
\hline & & $\mathrm{X} \rightarrow \mathrm{M} \rightarrow \mathrm{Y}(b)$ & 0.080 & .092 & \\
\hline & & $\mathrm{X} \rightarrow \mathrm{Y} \rightarrow \mathrm{M}\left(c^{\prime}\right)$ & - & - & \\
\hline & \multirow{4}{*}{$\begin{array}{l}\text { Epistemic } \\
\text { value }\end{array}$} & $\mathrm{X} \rightarrow \mathrm{Y}(c)$ & 0.590 & .000 & \multirow{4}{*}{$\begin{array}{c}\text { Partial } \\
\text { mediation }\end{array}$} \\
\hline & & $\mathrm{X} \rightarrow \mathrm{M}(a)$ & 0.697 & .000 & \\
\hline & & $\mathrm{X} \rightarrow \mathrm{M} \rightarrow \mathrm{Y}(b)$ & 0.285 & .000 & \\
\hline & & $\mathrm{X} \rightarrow \mathrm{Y} \rightarrow \mathrm{M}\left(c^{\prime}\right)$ & 0.330 & .000 & \\
\hline & \multirow{4}{*}{$\begin{array}{l}\text { Emotional } \\
\text { value }\end{array}$} & $\mathrm{X} \rightarrow \mathrm{Y}(c)$ & 0.590 & .000 & \multirow{4}{*}{\begin{tabular}{|c|}
$\mathrm{No}$ \\
mediation
\end{tabular}} \\
\hline & & $\mathrm{X} \rightarrow \mathrm{M}(a)$ & 0.248 & .000 & \\
\hline & & $\mathrm{X} \rightarrow \mathrm{M} \rightarrow \mathrm{Y}(b)$ & 0.037 & .0291 & \\
\hline & & $\mathrm{X} \rightarrow \mathrm{Y} \rightarrow \mathrm{M}\left(c^{\prime}\right)$ & - & - & \\
\hline
\end{tabular}

Overall, the perceived value did not mediate the relationship between environmental knowledge and revisit intention to green resorts. Nevertheless, the study proved that functional value and epistemic value partially mediate the relationship between environmental awareness and revisit intention to the green resorts, given the reduction in the influence of environmental awareness after the inclusion of both mediators. Despite that, both relationships' reduction was significantly different from zero; thus, reaffirming the partial mediation effect.

\section{Discussion of Findings}

The regression analysis of the study showed that environmental concern had a substantial positive correlation with the desire to return to green resorts, based on hypothesis testing. Aman et al. (2012) found that environmental concerns substantially impacted green purchase intention, and our results support their findings. According to Irawan and Darmayanti (2012), environmental concerns strongly affected green purchasing behaviour among many Indonesian university students. Environmentalism and epistemic value were shown to impact behavioural intention, while environmental concern was found to have an impact on behavioural intention. Researchers hypothesised that environmental knowledge did not impact green purchase behaviour (Patel et al., 2017; Wu et al., 2018).

Environmental awareness in this study reflects the concern and apprehension towards the diverse facets of environmental problems. This finding is in line with that reported by Han et al. (2011) and Trang et al. (2019). The results of hypotheses testing also showed a significant relationship between environmental concern and guests' perceived value. This is in line with the study conducted by Shamah et al. (2016), which claimed the individuals with adequate concern about the environment had a better understanding of environmental protection actions and usually generated positive feelings due to performing green behaviour. According to the findings, environmental information has a considerable impact on perceived social worth, epistemic value, and emotional value. In terms of functional value, the current study's findings demonstrated that functional value had the greatest impact on revisit intention. The results align with Azam et al., (2017) which shows that visitors consider the functional value to be the most important consideration in their decision-making.

When visitors to green resorts have a thirst for knowledge and are intrigued by the attributes of green resorts, epistemic value emerges. The findings on epistemic value agree with those of Mutum et al. (2021), who discovered a positive relationship between epistemic value and sustainable consumption and green purchasing behaviour. This validates the epistemic value's projected primary advantages for the tourist experience. According to the findings, neither social nor emotional values had a significant impact on revisit intention. Zhang et al. (2018) countered the previous results by demonstrating the importance of social value on the choice to remain or intend to return. According to Azam et al. (2017), the social value had a key impact in visitors' perceptions of their stay at a green resort. The impact of social needs and selfimage on green purchasing intentions was also discussed by Kautish and Sharma (2019).

The main purpose of this study was to investigate whether the dimensions of perceived value had a role in mediating the link between environmental concern and the desire to return to green resorts. The empirical outcomes of this study failed to 
support the hypotheses $\left(\mathrm{H} 4_{\mathrm{a}}, \mathrm{H} 4_{\mathrm{b}},{ }_{\mathrm{H}} 4_{\mathrm{c}}\right.$, and $\left.\mathrm{H} 4 \mathrm{~d}\right)$. There was no mediation effect of perceived functional, social, epistemic, and emotional values on the relationship between environmental knowledge and customers' intention to revisit green resorts. Based on the findings, no mediation effect of perceived value was noted in the relationship between environmental knowledge and revisit intention to green resorts. The results of $\mathrm{H} 4_{\mathrm{a}}, \mathrm{H} 4_{\mathrm{b}}, \mathrm{H} 4_{\mathrm{c}}$, and $\mathrm{H} 4 \mathrm{~d}$ are not in line with past studies, as several past studies demonstrated the mediating role of perceived value in the relationship between environmental knowledge and revisit intention to green hotels (Song et al., 2017; Szabo and Webster, 2021). The findings reaffirmed customers' insufficient level of environmental knowledge, which influenced their decision-making process (Bangsa and Schlegelmilch, 2020; Verma and Chandra, 2018). Nevertheless, this study's social and emotional values did not establish any mediating role between environmental awareness and revisit intention to green resorts. Shamah et al. (2016) emphasised the role of perceived value in elaborating the behavioural intention in the pre-purchase stage among green hotel guests, which pointed out the insignificant mediating role of perceived value in the correlation between environmental concern and behavioural intention. Nevertheless, this present study exemplifies environmental knowledge (no mediation effect) and environmental awareness (did not directly explain the variance in revisit intention). To a certain extent, these are partially mediated by external factors, particularly functional and epistemic values in the post-purchase stage.

\section{Theoretical Contributions}

Theoretically, researchers can construct a framework for perceived value, environmental concern and revisit intention in the context of green resorts. It was shown that there was an inverse correlation between environmental concern, perceived value, and desire to return to green resorts when the SET was used as a foundational theory. The SET postulates the willingness to exchange if one receives a reward and when benefits outweigh costs (Zietsman et al., 2020). Essentially, SET considers the exchange as the basis of human behaviour (Nunkoo, 2016). The construction of this framework adds to the body of knowledge about guest assessment structures. This empirical research adds to our understanding of the importance of integrating these variables when evaluating resort customers' travel experiences. Various environmental concern and perceived value characteristics were employed as significant elements in guest evaluations of return intention in this research. This research may test the exclusive link between environmental concern and perceived value simultaneously, yielding more significant results. The mediating effect of perceived value in terms of functional, emotional, social, and epistemic values in the link between characteristics of environmental concern and revisit intention is explored in this research. Overall, the study outcomes offer empirical evidence on the developed framework about revisit intention within the context of green resorts, including the strength of the relationships of environmental concern, perceived value, and revisit intention. Although the items of environmental concern, perceived value, and revisit intention in this study were adapted from past studies, this study contributes to the methodological aspect by illustrating the reliability and validity of these items in different settings and contexts, namely green resorts located in Malaysia.

\section{Limitations of Study and Recommendations for Future Research}

Future studies should look at additional characteristics that might explain the differences in return intentions. For example, elements like appeal, attitude, and contentment might impact the link between perceived value and the likelihood of a return visit. Various characteristics of perceived value are critical, and they are dependent on the decision level and the sorts of items or services, according to Sweeney and Soutar (2001). For future study, it's also advised to look at other possible mediators in this exclusive link between environmental concern and revisit intention, such as selfidentity and green image. Lastly, there are the data processing and analytic processes. Multiple regression analysis is known for its ability to predict the strength of relationships between variables. This method provides regression coefficients equivalent to more advanced analytical techniques, such as LISREL's structural equation modelling (SEM) (Hayes, 2013). The primary flaw of multiple regression analysis is its inability to account for random measurement error or the qualities or conditions that influence variable measurement, which is addressed in SEM. Since SEM may effectively include the whole range of existing multivariate analytic techniques, future research should consider using it.

\section{CONCLUSION}

The major goal of this research is to determine how perceived value influences the desire to return to green resorts. This research looked at the direct association between environmental concern and revisit intention and the indirect relationship between revisit intention and environmental concern through perceived value. There have been few studies on the impact of other aspects of perceived value, like epistemic values, functional, revisit intention, and social, emotional on revisit intention. Perceived value is described as the key to interpreting visitor behaviour in marketing literature. Green value has been deemed as an insignificant mediator for intention to purchase. Thus, there is a need to assess the mechanism of mediating variables in the relationship between perceived value and revisit intention (Yang and Youngtae, 2015). In addressing this gap, this present study extends the existing knowledge based on destination marketing by developing an integrated research framework. This study enhances the understanding of the varied dimensions of perceived value (i.e., functional, emotional, social, and epistemic values) as the mediator between various dimensions of environmental concern and revisit intention among green resort guests.

\section{REFERENCES}

Abubakar, A.M., Elrehail, H., Alatailat, M.A., \& Elçi, A. (2019). Knowledge management, decision-making style and sorganisational performance. Journal of Innovation \& Knowledge, 4(2), 104-114. https://doi.org/10.1016/j.jik.2017.07.003 
Adnan, A., Ahmad, A., \& Khan, M.N. (2017). Examining the role of consumer lifestyles on ecological behavior among young Indian consumers. Young Consumers, 18(4), 348-377. https://doi.org/10.1108/YC-05-2017-00699

Ahn, J., \& Kwon, J. (2020). Green hotel brands in Malaysia: perceived value, cost, anticipated emotion, and revisit Intention. Current Issues in Tourism, 23(12), 1559-1574. https://doi.org/10.1080/13683500.2019.1646715

Aman, A.H.L., Harun, A., \& Hussein, Z. (2012). The influence of environmental knowledge and concern on green purchase intention the role of attitude as a mediating variable. British Journal of Art and Social Sciences, 7 (2), 145 - 167. http://dx.doi.org/10.18415/ijmmu.v6i2.706

An, S., Suh, J., \& Eck, T. (2019). Examining structural relationships among service quality, perceived value, satisfaction and revisit Intention for airbnb guests. International Journal of Tourism Sciences, 19(3), 145-165. https://doi.org/10.1080/15980634.2019.1663980

Ashraf, M.S., Hou, F., Kim, W.G., Ahmad, W., \& Ashraf, R.U. (2020). Modeling tourists' visiting intentions toward ecofriendly destinations: Implications for sustainable tourism operators. Business Strategy and the Environment, 29(1), 54-71. https://doi.org/10.1002/bse.2350

Azali, M., Kamal Basha, N., Chang, Y.S., Lim, X.J., \& Cheah, J.H. (2021). Why not travel to Malaysia? Variations in inbound tourists' perceptions toward Halal-friendly destination attributes. Journal of Hospitality \& Tourism Research, 1096348020987634 https://doi.org/10.1177/1096348020987634

Azam, N.R.A.N., Rashid, B., Zainol, N.A., \& Mohamad, M. (2020). Multi-dimensional values on customers' intention to revisit green resorts: The cultural case in Malaysia. Journal of Innovation in Educational and Cultural Research, 1(2), 41-51. https://doi.org/10.46843/jiecr.v1i2.8

Azam, N.R.A., Rashid, B., \& Zainol, N.A. (2017). sConceptualising the influence of environmental knowledge on perceived visit value to green resort in Malaysia. Journal of Tourism, Hospitality and Environment Management, 2(5), 1-17. http://repo.uum.edu.my/26350/

Bangsa, A.B., \& Schlegelmilch, B.B. (2020). Linking sustainable product attributes and consumer decision-making: Insights from a systematic review. Journal of Cleaner Production, 245, 118902. https://doi.org/10.1016/j.jclepro.2019.118902

Barron, R.M., \& Kenny, D.A. (1986). The moderator-mediator variable distinction in social psychology research: Conceptual, strategic, and statistical consideration. Journal of Personality and Social Psychology, 51(6), 1173-1182. https://psycnet.apa.org/doi/10. 1037/0022-3514.51.6.1173

Borhan, H., Vahidi, A., Phillips, A. M., Kuang, M. L., Kolmanovsky, I. V., \& Cairano, S. D. (2012). MPC-based energy management of a power-split hybrid electric vehicle. IEEE Transactions on Control Systems Technology, 20. https://cecas.clemson.edu/ avahidi/wpcontent/uploads/2016/10/alijournal.pdf

Churchill, G.A.Jr. (1995). Marketing research: Methodological foundations. New York, USA: The Drydeu Press. https://doi.org/10. $1080 / 00913367.1978 .10672747$

Collis, J., \& Hussey, R. (2009). Business research: A practical guide for undergraduate and postgraduate students (3 ${ }^{\text {rd }}$ ed.). New York: Palgrave Macmillan. https://doi.org/10.2323/su12218789.

Cruz, S.M. (2017). The relationships of political ideology and party affiliation with environmental concern: A meta-analysis. Journal of Environmental Psychology, 53, 81-91. https://doi.org/10.1016/i.jenvp.2017.06.010

Fraccaro, A., Macé, S., \& Parguel, B. (2021). The not-so-odd couple: Odd pricing in a luxury context. Journal of Business Research, 136, 356-365. https://doi.org/10.1016/j.jbusres.2021.07.048

Grewal, D., \& Roggeveen, A.L. (2020). Understanding retail experiences and customer journey management. Journal of Retailing, 96(1), 3-8. https://doi.org/10.1016/j.jretai.2020.02.002

Hair, J.F., Black, W.C., Babin, B.J., \& Anderson, R.E. (2010). Multivariate data analysis ( $7^{\text {th }}$ ed.). Prentice Hall, Upper Saddle River, New Jersey. https://doi.org/10.1222/18232324.2017.1318590

Han, H., Hsu, L.T., Lee, J.S., \& Sheu, C. (2011). Are lodging customers ready to go green? An examination of attitudes, demographics, and ecofriendly decisions. International Journal of Hospitality Management, 30(1), 345-355. https://doi.org/10.1016/j.ijhm.2010.07.008

Hayes, A.F. (2013). Introduction to Mediation, Moderation, and Conditional Process Analysis: A Regression-Based Approach. New York, NY: Guilford Press. . https://doi.org/11.23212323/su12273729

Hodgson, P. (1990). New tourism product development: Market research's role. Tourism Management, 11(1), 2-5. https://doi.org/10. 1016/0261-5177(90)90002-Q

Huh, C., \& Chang, H. (2017). An investigation of generation y travellers' beliefs and attitudes towards green hotel practices: A view from active and passive green generation y travelers. International Journal Tourism Science, 17, 126-139. https://doi.org/10.1080/15980634.2017.1318590

Irawan, R., \& Darmayanti, D. (2012). The influence factors of green purchasing behavior: A study of university students in Jakarta. http://www.wbiconpro.com/517\%20-\%20Dahlia.pdf

Joshi, Y., \& Rahman, Z. (2019). Consumers' sustainable purchase behaviour: Modeling the impact of psychological factors. Ecological economics, 159, 235-243. https://doi.org/10.1016/j.ecolecon.2019.01.025

Kautish, P., \& Sharma, R. (2019). Value orientation, green attitude and green behavioral intentions: an empirical investigation among young consumers. Young Consumers, 20(4), 338-358. https://doi.org/10.1108/YC-11-2018-0881

Khan, M.S., Saengon, P., Alganad, A.M.N., Chongcharoen, D., \& Farrukh, M. (2020). Consumer green behaviour: An approach towards environmental sustainability. Sustainable Development, 28(5), 1168-1180. https://doi.org/10.1002/sd.2066

Kim, J., Kim, S., Lee, J.S., Kim, P.B., \& Cui, Y. (2020). Influence of choice architecture on the preference for a pro-environmental hotel. Journal of Travel Research, 59(3), 512-527. https://doi.org/10.1177\%2F0047287519841718

Kim, M.S., Kim, J., \& Thapa, B. (2018). Influence of environmental knowledge on affect, nature affiliation and pro-environmental behaviors among tourists. Sustainability, 10(9), 3109. https://doi.org/10.3390/su10093109

Kozak, M., \& Baloglu, S. (2011). Managing and marketing tourist destinations: Strategies to gain a competitive edge. New York: Routledge.

Lukuyu, B., Place, F., Franzel, S., \& Kiptot, E. (2012). Disseminating improved practices: are volunteer farmer trainers effective?. The Journal of Agricultural Education and Extension, 18(5), 525-540. https://doi.org/10.1080/1389224X.2012.707066

Mutum, D.S., Ghazali, E.M., \& Pin, W. (2021). Parallel mediation effect of consumption values and the moderation effect of innovativeness, in predicting the influence of identity on green purchasing behavior. Journal of Consumer Behaviour, 20(3), 827844. https://doi.org/10.1002/cb.1913

Nunkoo, R. (2016). Toward a more comprehensive use of social exchange theory to study residents' attitudes to tourism. Procedia Economics and Finance, 39, 588-596. https://doi.org/10.1016/S2212-5671(16)30303-3

Park, H.Y., \& Kim, D.K. (2017). In pursuit of an environmentally friendly convention industry: A sustainability framework and guidelines for a green convention. International Journal of Contemporary Hospitality Management, 29(3), 1028-1051. https://doi.org/10. 1108/IJCHM-06-2016-0333 
Patel, J., Modi, A., \& Paul, J. (2017). Pro-environmental behavior and socio-demographic factors in an emerging market. Asian Journal of Business Ethics, 6(2), 189-214. https://doi.org/10.1007/s13520-016-0071-5

Rasheed, T., Bilal, M., Nabeel, F., Adeel, M., \& Iqbal, H.M. (2019). Environmentally-related contaminants of high concern: potential sources and analytical modalities for detection, quantification, and treatment. Environment international, 122, 52-66. https://doi.org/ 10.1016/j.envint.2018.11.038

Rashid, B. (2013). Post visit assessment: The influence of consumption emotion on tourist future intention https://doi.org/10.1108/JIMA10-2018-0194on. Journal of Business and Management, 9(3), 39-45. https://doi.org/10.9790/487X-0933945

Saeed, B.B., Afsar, B., Hafeez, S., Khan, I., Tahir, M., \& Afridi, M.A. (2019). Promoting employee's proenvironmental behavior through green human resource management practices. Corporate Social Responsibility and Environmental Management, 26(2), 424-438. https://doi.org/10.1002/csr.1694

Saeed, M., Grine, F. \& Shafique, I. (2020). Integrating Factors Influencing Hijab Purchase Intention among Muslim Women. Journal of Islamic Marketing, 12(1), 95-112. https://doi.org/10.1108/JIMA-10-2018-0194

Salunke, S., Weerawardena, J., \& Kennedy, J.R.M. (2019). The central role of knowledge integration capability in service innovationbased competitive strategy. Industrial Marketing Management, 76, 144-156. https://doi.org/10.1016/j.indmarman.2018.07.004

Samudro, A., Sumarwan, U., Yusuf, E.Z., \& Simanjuntak, M. (2018). Perceived value, social bond, and switching cost as antecedents and predictors of customer loyalty in the B2B chemical industry context: A literature review. International Journal of Marketing Studies, 10(4), 124-138. https://doi.org/10.5539/ijms.v10n4p124

Sekaran, U., \& Bougie, R. (2010). Research methods for business: A skill building approach (5 ${ }^{\text {th }}$ ed.). New Delhi: Wiley India.

Shamah, R.A., Mason, M.C., Moretti, A., \& Raggiotto, F. (2018). Investigating the antecedents of African fast food customers' loyalty: A self-congruity perspective. Journal of Business Research, 86, 446-456. https://doi.org/10.1016/j.jbusres.2017.05.020

Shams, R., Vrontis, D., Belyaeva, Z., Ferraris, A., \& Czinkota, M.R. (2021). Strategic agility in international business: A conceptual framework for "agile" multinationals. Journal of International Management, 27(1), 100737. https://doi.org/10.1016/i.intman.2020.100737

Sheth, J.N., Newman, B.I., \& Gross, B.L. (1991). Why we buy what we buy: A theory of consumption values. Journal of business research, 22(2), 159-170. https://doi.org/10.1016/0148-2963(91)90050-8

Song, H.M., Kim, K.S., \& Yim, B.H. (2017). The mediating effect of place attachment on the relationship between golf tourism destination image and revisit intention. Asia Pacific Journal of Tourism Research, 22(11), 1182-1193. https://doi.org/10.1080/10941665.2017.1377740

Su, L., \& Swanson, S.R. (2017). The effect of destination social responsibility on tourist environmentally responsible behavior: Compared analysis of first-time and repeat tourists. Tourism Management, 60, 308-321. https://doi.org/10.1016/..tourman.2016.12.011

Suki, N.M., Majeed, A., \& Suki, N.M. (2021). Impact of consumption values on consumers' purchase of organic food and green environmental concerns. Social Responsibility Journal. https://doi.org/10.1108/SRJ-01-2021-0026

Sweeney, J.C., \& Soutar, G. (2001). Consumer perceived value: the development of multiple item scale, Journal of Retailing, 77 (2), 203-20. https://doi.org/10.1016/S0022-4359(01)00041-0

Szabo, S., \& Webster, J. (2021). Perceived greenwashing: the effects of green marketing on environmental and product perceptions. Journal of Business Ethics, 171(4), 719-739. https://doi.org/10.1007/s10551-020-04461-0

Trang, H.L.T., Lee, J.S., \& Han, H. (2019). How do green attributes elicit pro-environmental behaviors in guests? The case of green hotels in Vietnam. Journal of Travel \& Tourism Marketing, 36(1), 14-28. https://doi.org/10.1080/10548408.2018.1486782

Verma, V.K., \& Chandra, B. (2018). An application of theory of planned behavior to predict young Indian consumers' green hotel visit intention. Journal of cleaner production, 172, 1152-1162. https://doi.org/10.1016/j.jclepro.2017.10.047

Wang, S., Wang, J., Wang, Y., Yan, J., \& Li, J. (2018). Environmental knowledge and consumers' intentions to visit green hotels: The mediating role of consumption values. Journal of Travel \& Tourism Marketing, 35(9), 1261-1271. https://doi.org/10. 1080/10548408.2018.1490234

Wang, Y., Gu, J., Wang, S., \& Wang, J. (2019). Understanding consumers' willingness to use ride-sharing services: The roles of perceived value and perceived risk. Transportation Research Part C: Emerging Technologies, 105, 504-519. https://doi.org/10.1016/j.trc.2019.05.044

Wu, H.C., Cheng, C.C., \& Ai, C.H. (2018). A study of experiential quality, experiential value, trust, corporate reputation, experiential satisfaction and behavioral intentions for cruise tourists: The case of Hong Kong. Tourism Management, 66, 200-220. https://doi.org/10.1016/j.tourman.2017.12.011

Yang, J., \& Youngtae, K. (2015). Developing multi-dimensional green value: Extending Social Exchange Theory to explore customers' purchase intention in green hotels - evidence from Korea. International Journal of Contemporary Hospitality Management, 27(2), 308-334. https://doi.org/ 10.1108/IJCHM-08-2013-0383

Yrjölä, M., Rintamäki, T., Saarijärvi, H., Joensuu, J., \& Kulkarni, G. (2019). A customer value perspective to service experiences in restaurants. Journal of Retailing and Consumer Services, 51, 91-101. https://doi.org/10.1016/i.jretconser.2019.05.030

Zhang, G., \& He, B.J. (2021). Towards green roof implementation: Drivers, motivations, barriers and recommendations. Urban Forestry \& Urban Greening, 58 126992. https://doi.org/10.1016/i.ufug.2021.126992

Zhang, L., Li, D., Cao, C., \& Huang, S. (2018). The influence of greenwashing perception on green purchasing intentions: The mediating role of green word-of-mouth and moderating role of green concern. Journal of Cleaner Production, 187, 740-750. https://doi.org/10.1016/j.iclepro.2018.03.201

Zhang, T.C., Jahromi, M.F., \& Kizildag, M. (2018). Value co-creation in a sharing economy: the end of price wars?. International Journal of Hospitality Management, 71, 51-58. https://doi.org/10.1016/j.j.jhm.2017.11.010

Zietsman, M.L., Mostert, P., \& Svensson, G. (2020). A multidimensional approach to the outcomes of perceived value in business relationships. European Business Review, 32(4),709-729. https://doi.org/10.1108/EBR-10-2019-0258

Article history: Received: 19.09.2021 Revised: 11.12.2021 Accepted: 17.01.2022 Available online: 09.02.2022 